\title{
Stability of Soil Organic Matter and Soil Loss Dynamics under Short-term Soil Moisture Change Regimes
}

\section{Parwada $\mathbf{C}^{1,2 *}$ and van Tol $\mathbf{J}^{1,3}$}

${ }^{1}$ Department of Agronomy, University of Fort Hare, Alice, South Africa

${ }^{2}$ Department of Crop Science, Bindura University of Science Education, Bindura, Zimbabwe

${ }^{3}$ Department of Soil-and Crop-and Climate Sciences, University of the Free State, Bloemfontein, South Africa

\begin{abstract}
Soil properties are known to be influenced Soil Organic Matter (SOM) resident time. However, there is limited information on the interactive effects of SOM quality and soil moisture on SOC and Microbial Biomass Carbon (MBC) hence on soil losses. Therefore, this study investigated the effects of different organic matter and soil moisture in soils with low $(<2 \%)$ initial SOC content on the SOC, MBC and soil loss with time of organic matter incorporation. Six soils were incubated for 34 weeks at $25^{\circ} \mathrm{C}$ after adding high quality $(\mathrm{C} / \mathrm{N}=23)$ Vachellia karroo leaf litter and low quality $(\mathrm{C} / \mathrm{N}=41)$ Zea mays stover. The effect of SOM quality and soil moisture on the SOC content, MBC and soil loss was significantly $(P<0.05)$ the same within but varied across soils. Soils that were continuously wet lost more SOC than under alternating wet-dry moisture conditions. Microbial biomass carbon was controlled by the availability of organic matter and moist soil conditions. Low MBC values corresponded to high SOC and soil loss. Continuously wet soils with high sand particles promoted rapid loss of SOC compared to alternating wet-dry soils. Therefore, continuously wet sandy soils are likely to contribute more to the climate warming than alternating wet-dry soil moisture. In the wake of the climatic change, addition of OM in continuously wet soils need to be regulated but to reduce soil loss re-application of fresh OM has to be more frequent under continuously wet sandy soils than in alternating wet-dry moisture regimes.
\end{abstract}

Keywords: Carbon emission; Conservation; erosion; Mineralization; Texture

\section{Introduction}

The interaction between climate change and the global carbon cycle is an important aspect of the global environmental changes [1]. Soil is the largest pool of terrestrial organic carbon in biosphere, storing more Carbon (C) [2]. Therefore, the Soil Organic Carbon (SOC) stock has an irreplaceable function in mitigating climate change as a key component of the biosphere carbon cycle. Meaning that changes in SOC content significantly influence climate change and a slight change in the SOC stocks can have a considerable effects on atmospheric carbon dioxide concentration, contributing to climate warming [3]. Changes of the climate, particularly the temperature and rainfall have more pronounced effects on the resident period of the SOC by accelerating SOC decomposition offsetting a portion of the SOC losses. However, many researches relating the climate change to SOC are biased towards revealing the trends and future projection changes in the SOC and its effects on the environment, ignoring the current climatic scenarios. The climate change is manifested by changes in temperature, precipitation and length of the season [4]. Precipitations that are punctuated by prolonged mid-season dry spells are now a common phenomenon in many parts of the world and could result to detrimental effects on soil microbial action on SOC hence soil losses through erosion. The climatic factors affect the soil microbial activities on the Soil Organic Matter (SOM) thereby influencing the SOM resident period [5].

The climate change modifies soil temperature and moisture simultaneously and, although many researches have attempted to determine the effect of litter quality or moisture on soil microbial biomass, there is still limited attempts to explore the combined effects of both factors [6,7]. The influence of soil moisture on soil carbon stocks has received relatively little attention, although it has a key role in regulating the soil microbial activity [8]. There is also very limited understanding of how intermittent soil moisture affects the soil organic matter decomposition, as the relationships between the intermittent moisture content and quality of soil organic matter are not consistent across different soils.

In addition to the climatic factors, the quality of soil organic matter should also affect the rate of decomposition [9]. Several studies have indicated that the chemical and biochemical quality of litter affects mass loss during decomposition [10,11]. The addition of higher quality substrate (lower $\mathrm{C} / \mathrm{N}$ ratio of $<24$ and lower lignin content) resulted to increased SOC mineralization compared to the addition of lower quality $(\mathrm{C} / \mathrm{N}$ ratio $>24)$ substrate [12-14]. Since the soil microbes need $\mathrm{N}$ (and other essential elements) as well as $\mathrm{C}$, if there is little $\mathrm{N}$ in the residue, decomposition is slow. When immature legumes are ploughed into the soil that had lower dry matter but higher $\mathrm{N}$ concentration and low $\mathrm{C} / \mathrm{N}$, decomposition was faster [10]. On the other hand, the high cellulose, hemicellulose and lignin contents of legumes ploughed in at a matured age reduced the speed of decomposition. The $\mathrm{C} / \mathrm{N}$ ratio in plant residues is highly variable and increases with maturity. An ideal substrate material was found to have $\mathrm{C} / \mathrm{N}$ ratio $=24$ to satisfy the $\mathrm{N}$ requirement of microbes $[12,13]$. If the $\mathrm{C} / \mathrm{N}$ ratio of residue $>24$, available soil $\mathrm{N}$ is consumed by microbes and this retards decomposition rate. A number of authors have reported linear increases in SOC related to the amount of organic matter applied, whilst others, have reported that the rate of SOC accumulation is dependent on the source of organic carbon [14-16]. This greatly suggests

${ }^{*}$ Corresponding author: Parwada C, Department of Agronomy, University of Fort Hare, Alice, South Africa, Tel: 2773394154; E-mail: cparwada@gmail.com

Received July 17, 2017; Accepted July 25, 2017; Published August 01, 2017

Citation: Parwada C, van Tol J (2017) Stability of Soil Organic Matter and Soil Loss Dynamics under Short-term Soil Moisture Change Regimes. Agrotechnology 6: 159. doi: 10.4172/2168-9881.1000159

Copyright: @ 2017 Parwada C, et al. This is an open-access article distributed under the terms of the Creative Commons Attribution License, which permits unrestricted use, distribution, and reproduction in any medium, provided the original author and source are credited. 
that litter quality is a major control factor of organic carbon content in various soils. Nevertheless, less is known about litter quality and SOC stabilization in different soils [17].

The SOC is one of the key factors influencing soil erodibility. This is due to the positive feedback of the SOC on soil quality as influenced by the Organic Matter (OM) [18]. The OM is the source of all SOC and the rate of OM decomposition in the soil has a direct effect on the amount of SOC present at any given time. Whilst any OM source can be used to enhance soil aggregation and stability, a major drawback is on ensuring selection of OM with clear and prolonged soil stabilizing effects. Different OM may have different effects on soil erodibility and organic carbon resident time depending on properties of the soil in question. Therefore, to maximize the benefits of OM in soil conservation, there is need to explore effects of various OM sources in stabilizing soils of different properties.

The patterns and controls of SOC storage are critical for our understanding of the biosphere, given the importance of SOC in the soil and the feedback to the atmosphere and the rate of climate change. The capacity to predict and ameliorate the consequences of climate change depends on a clear description of SOC content and controlling of SOC inputs and outputs [2]. One aspect of the organic carbon pool that remains poorly understood is its mineralization in different soils varying in moisture. What are the general patterns of SOC in different soils? Do the major determinants of SOC content differ with litter quality and soil moisture regime? How much SOC is stabilized in different soils especially under continuously wet and alternating wetdry soil moisture conditions and what is the effect of litter quality on the SOC? This paper aim to provide preliminary answers to these and other questions, based on laboratory soil-litter incubation experiments.

We hypothesize that litter source and soil moisture are the major determinant of the abundance of soil microbes that influence the SOC content at any given time. Although soil temperature and the primary particle sizes distribution of the soil are influential in controlling the distribution of SOC, may normally be overruled by the effects of plant type under natural conditions [2].

The specific objectives of this study were to: (1) Determine the effect of litter quality and soil moisture on SOC content, microbial biomass carbon $(\mathrm{MBC})$ soil loss changes with time in different areas of soil associations; and (2) Evaluate the relationship between the SOC content and Microbial Biomass Carbon (MBC) and soil loss dynamics in different areas of soil associations.

\section{Materials and Methods}

\section{Description of the study area}

The study was carried out in the soil physics laboratory at the University of Fort Hare (UFH), Eastern Cape Province (EC), and South Africa (SA). Soil used in the study were collected from the Ntabelanga area, EC, SA and is located about $380 \mathrm{~km}$ south east of the UFH and lies between $31^{\circ} 7^{\prime} 35.9^{\prime \prime} \mathrm{S}$ and $28^{\circ} 40^{\prime} 30.6^{\prime \prime} \mathrm{E}$. The soils were low $(<2 \%)$ organic carbon and unstable that are prone to erosion as evidenced by extensive areas of severe gully erosion on the inter-fluvial areas adjacent to stream channels. The Ntabelanga area is covered by land type $\mathrm{Db} 344$ that has only $10.2 \%$ of the soils with a low sensitivity to erosion. The majority, $71.3 \%$ of the area is covered by highly sensitive to erosion with the remaining $18.5 \%$ having moderate sensitivity to erosion $[19,20]$. The Ntabelanga area receives an annual rainfall total of about $749 \mathrm{~mm}$, with most of it falling in December and January. The rain season is characterised by prolonged mid-season dry spells with the lowest $(15 \mathrm{~mm})$ average rainfall received in June and the highest $(108 \mathrm{~mm})$ in January.

\section{Site selection and soil sampling}

This work followed on studies of Van Tol et al. [19,20]. In these studies the soils of land type Db344 were mapped in some detail. Based on these maps, areas of soil associations were identified and selected for sampling and incubation. Soils in an area of soil association are likely to behave the same to a certain treatment. Although this method included only nine sampling locations, these soils were representative of the majority of Db344. Twenty one soil samples were randomly collected using a zig zag pattern across a proposed Ntabelanga dam at the nine locations (Figure 1) representing the areas of soil associations (wet, melanic, apedal, semi-duplex, duplex and shallow). The soil samples were then compounded to six samples according to the existing areas of soil associations. The soils were collected basing on naturally existing horizons in each soil profile of the areas of soil associations. The soil profiles varied in depth; six were deeper than $30 \mathrm{~cm}$ and three shallow (i.e., $<30 \mathrm{~cm}$ ). Some of the sampling points were severely eroded and lacked the A horizon so that subsoils were exposed in many areas and others were rocky just below the A horizon meaning that the horizons were either in their natural or eroded conditions. The observed soil horizons were orthic A, melanic A, pedocutanic $\mathrm{B}$, red apedal B, prismacutanic B, and G-horizon.

\section{Laboratory soil incubation}

The soil was air dried and was passed through a $2 \mathrm{~mm}$ sieve to homogenize the aggregates. The $<2 \mathrm{~mm}$ soil aggregates were mixed to either Vachellia karroo leaves (low $\mathrm{C} / \mathrm{N}$ ) or Zea mays stover (high $\mathrm{C} / \mathrm{N}$ ). The $V$. karroo leaves were harvested at the beginning of winter season (May 2014) and Z. mays stover was from a harvested maize summer crop. The plant materials were shredded into very small segments and oven dried at $60^{\circ} \mathrm{C}$ then ground to pass through a $2 \mathrm{~mm}$ sieve. Subsamples of each ground litter were taken and measured for total C, N, lignin and polyphenols contents. The lignin (L) was determined by the Acid Detergent Fibre (ADF) method as outlined in Van Tol et al. [21]. The polyphenols were extracted in hot $\left(80^{\circ} \mathrm{C}\right) 50 \%$ aqueous methanol and determined calorimetrically with tannic acid as standard $[21,22]$.

A $600 \mathrm{~g}$ of each soil association was mixed with plant litter at a rate of $2.28 \mathrm{~g} \mathrm{OM}\left(100 \mathrm{~g} \mathrm{soil}^{-1}\right.$ and $2.43 \mathrm{~g} \mathrm{OM}(100 \mathrm{~g} \text { soil })^{-1}$ for $V$. karroo leaves and $Z$. mays stover respectively. The mixture constituted at least $2 \%$ Soil Organic Carbon (SOC) since initial SOC in the soil associations ranged from 0.7 to $1.35 \%$ (Table 1). Soil moisture was adjusted to $80 \%$ field capacity equivalent to $48 \mathrm{~g} \mathrm{H}_{2} \mathrm{O} 100 \mathrm{~g}^{-1}$ and put in $1000 \mathrm{~mL}$ jars then incubated at $25^{\circ} \mathrm{C}$ for 34 weeks alternating the moistures at three week interval from $80 \%$ field capacity (wet soil condition) to $40 \%$ field capacity equivalent to $24 \mathrm{~g} \mathrm{H}_{2} \mathrm{O}$ (dry soil condition) during the incubation period. In the experiment, soil amended with the $V$. karroo leaf or Z. mays stover but soil moisture was continuously maintained at the $80 \%$ field capacity (wet soil condition) for the entire incubation period were included and the treatments were triplicated. The changes in soil organic matter was obtained by repeatedly measuring the SOC and Microbial Biomass Carbon (MBC) from the jars at weeks 3, 14, 24 and 34 during incubation. Soil losses were also estimated at the same times.

\section{Analyses of primary soil particle size distribution and SOC}

The soils were analysed for primary particle size distribution by the 
Citation: Parwada C, van Tol J (2017) Stability of Soil Organic Matter and Soil Loss Dynamics under Short-term Soil Moisture Change Regimes. Agrotechnology 6: 159. doi: 10.4172/2168-9881.1000159

Page 3 of 8

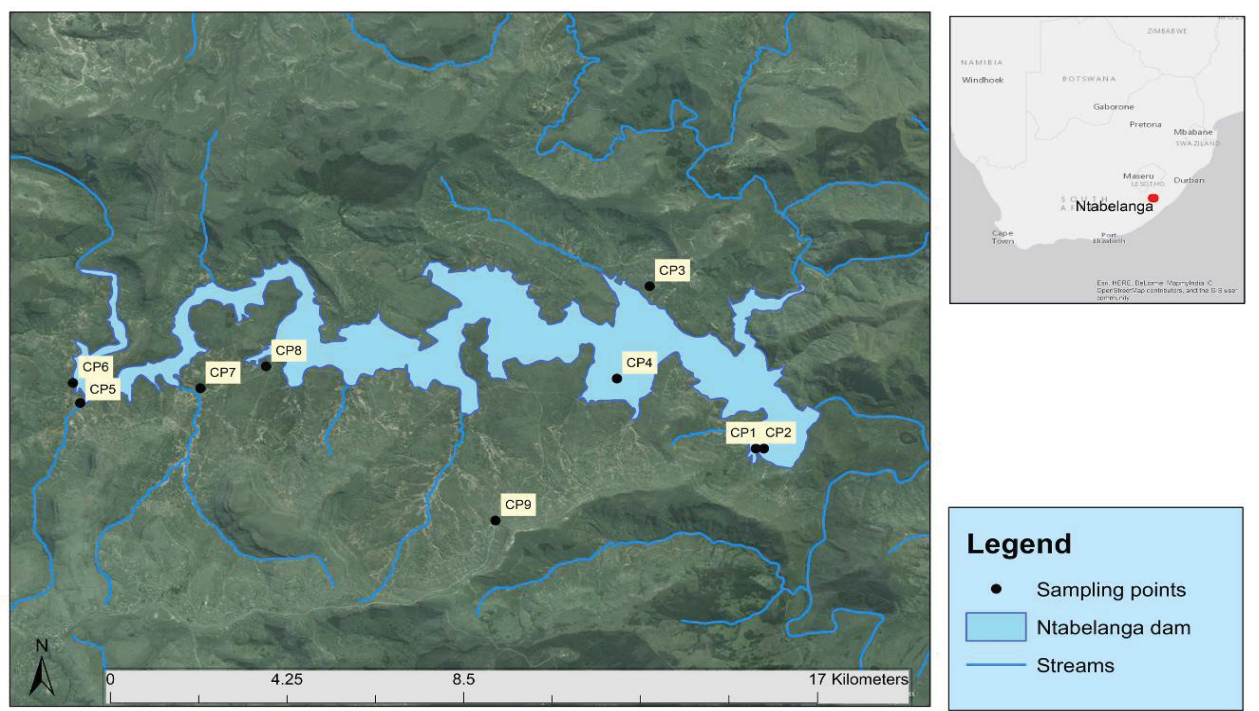

Figure 1: The randomly selected sampled points representing the areas of soil associations in the Ntabelanga area (Adapted from Parwada and Van Tol [40]).

\begin{tabular}{|c|c|c|c|c|c|c|c|c|}
\hline $\begin{array}{c}\text { Soil } \\
\text { association }\end{array}$ & Horizon & $\begin{array}{c}\text { South African soil } \\
\text { form* }^{*}\end{array}$ & $\begin{array}{l}\text { WRB } \\
\text { reference }^{* *}\end{array}$ & Characteristics & Sand $(\%)$ & Clay (\%) & Silt (\%) & SOC (\%) \\
\hline Shallow & Orthic A (ot) & Glenrosa & Leptosols & $\begin{array}{l}\text { Rock or rock horizon such as } \\
\text { Lithocutanic } B \text { as second horizon }\end{array}$ & 57.8 & 23.6 & 18.6 & 0.81 \\
\hline Wet & G-horizon (gh) & Katspruit & Gleysols & Water logged subsoil horizon & 47.5 & 27.5 & 25 & 0.53 \\
\hline Melanic & Melanic A (ml) & Boheim & Phaozems & Pedocutanic B & 18 & 62.5 & 19.5 & 0.39 \\
\hline Semi-duplex & Pedocutanic B (vp) & Valsrivier & $\begin{array}{l}\text { Chromic } \\
\text { Luvisols }\end{array}$ & $\begin{array}{l}\text { Moderate degree of structure in the } \\
\text { subsoil horizon }\end{array}$ & 21 & 59 & 20 & 0.39 \\
\hline Apedal & Red apedal B (re) & Hutton & $\begin{array}{l}\text { Ochric } \\
\text { Ferralsols }\end{array}$ & Apedal subsoil horizon & 49.5 & 31 & 19.5 & 1.35 \\
\hline Duplex & Prismacutanic B (pr) & Kroonstad & Stagnosols & $\begin{array}{l}\text { Sandy topsoil on clayey prismacutanic } \\
\text { B subsoil horizon }\end{array}$ & 36 & 38 & 26 & 0.7 \\
\hline- & - & - & - & $\pm S D$ & 17.4 & 16.8 & 4.1 & 0.4 \\
\hline
\end{tabular}

Table 1: Descriptive statistics of mean soil particle size distribution, initial Soil Organic Carbon (SOC) content of the soil associations used in the incubation experiments

hydrometer method as described by Okalebo et al. [23] and SOC was determined through the wet acid digestion modified Walkley Black method [24]. A gram of air-dried soil was transferred to a $500 \mathrm{~cm}^{3}$ Erlenmeyer flask and $10 \mathrm{~cm}^{3} \mathrm{~K}_{2} \mathrm{Cr}_{2} \mathrm{O}_{7}$ solution was added by pipette to the soil sample. The flask was swirled to disperse the soil in the solution then $20 \mathrm{~cm}^{3}$ concentrated sulphuric acid was rapidly added, directing the stream into the solution. The flask was swirled again gently until soil and the reagents were mixed, and then swirled more vigorously for a total time of $1 \mathrm{~min}$. The flask was allowed to cool on a sheet of asbestos for $30 \mathrm{~min}$ and then $150 \mathrm{~cm}^{3}$ de-ionised water, $10 \mathrm{~cm}^{3}$ concentrated ortho-phosphoric acid and $1 \mathrm{~cm}^{3}$ indicator were added. The excess dichromate with iron (II) ammonium sulphate solution was titrated, as the endpoint was approached, the solution colour changed to a dark violet brown. The iron (II) ammonium sulphate was added drop by drop until the colour changed sharply to green. Then the total organic carbon was calculated as follows:

Concetration of $\mathrm{Fe}\left(\mathrm{NH}_{4}\right)_{2}\left(\mathrm{SO}_{4}\right)_{2} \mathrm{~mol} \mathrm{dm} m^{-3}=\frac{10 \mathrm{~cm}^{3} \mathrm{~K}_{2} \mathrm{Cr}_{2} \mathrm{O}_{7} \times 0.167 \times 6}{\mathrm{~cm}^{3} \mathrm{Fe}\left(\mathrm{NH}_{4}\right)_{2}\left(\mathrm{SO}_{4}\right)_{2}}$

Organic $\mathrm{C} \%=\frac{\left[\mathrm{cm}^{3} \mathrm{Fe}\left(\mathrm{NH}_{4}\right)_{2}\left(\mathrm{SO}_{4}\right)_{2} \text { blank }-\mathrm{cm}^{3} \mathrm{Fe}\left(\mathrm{NH}_{4}\right)_{2}\left(\mathrm{SO}_{4}\right)_{2} \text { sample }\right] \times M \times 0.3 \times f}{\text { soil mass }(\mathrm{g})}$

Where $\mathrm{M}=$ Concentration of the $\mathrm{Fe}\left(\mathrm{NH}_{4}\right)_{2}\left(\mathrm{SO}_{4}\right)_{2}\left[\mathrm{~mol} \mathrm{dm}{ }^{-3}\right]$ and $\mathrm{f}=1.3$ (recovery factor).

\section{Determination of Microbial Biomass Carbon (MBC)}

The Chloroform Fumigation-Extract (CFE) procedure was used for determination of MBC during the soil incubation based on the methods of Anderson and Ingram [21]. Briefly, two $15 \mathrm{~g}$ of fresh soil of the incubated soil with known moisture content were weighed into a crucible and put into separate desiccators. In the other desiccator, a 100 $\mathrm{mL}$ beaker containing $25 \mathrm{~mL}$ of alcohol free chloroform with boiling chips was placed and a vacuum applied. The vacuum was applied to the fumigated soils samples until the chloroform was rapidly boiling, and then sealed and placed in a dark cupboard for $24 \mathrm{~h}$ at $25^{\circ} \mathrm{C}$. The nonfumigated soil samples were also incubated the same as the fumigated soils in the dark but without a vacuum. The fumigated soil samples were evacuated using a vacuum pump for 5 min with each evacuation lasting at least $2 \mathrm{~min}$. After evacuation, all the desiccators were opened and the organic carbon in the samples was extracted using $50 \mathrm{mh}$ of $0.5 \mathrm{M}$ potassium sulphate on a shaker at $180 \mathrm{rpm}$ for $1 \mathrm{~h}$ and filtered using Whatman No. 42 filter paper. Organic $\mathrm{C}$ in the extracts was then determined using the dichromate oxidation method and calculated using an equation proposed by Anderson and Ingram; Joergensen and Emmerling [21,25].

$$
c(\mu g / g-s o i l)=\frac{(H B-S) \times N \times E \times V D \times(V K+S W) \times 1000}{C B \times V S \times D M}
$$


Where $\mathrm{HB}=$ Consumption of titration solution by hot blank $(\mathrm{mL})$; $\mathrm{S}=$ Consumption of titration solution by sample $(\mathrm{mL}) ; \mathrm{N}=$ Normality of the $\mathrm{K}_{2} \mathrm{Cr}_{2} \mathrm{O}_{7} ; \mathrm{E}=3 ; \mathrm{VD}=$ Added volume of $\mathrm{K}_{2} \mathrm{Cr}_{2} \mathrm{O}_{7}(\mathrm{~mL})$; VS=Added volume of sample $(\mathrm{mL}) ; \mathrm{VK}=$ Volume of $\mathrm{K}_{2} \mathrm{SO}_{4}$ extractant $(\mathrm{mL}) ; \mathrm{CB}=$ Consumption of titration solution by cold blank $(\mathrm{mL})$; $\mathrm{SW}=$ Amount of water in the incubated soil sample $(\mathrm{mL})$; $\mathrm{DM}=$ Total mass dry soil (g).

The microbial biomass carbon $(\mathrm{MBC})$ was then calculated as:

$M B C=\frac{\text { (organic } C \text { in fumigated soil }- \text { organic } C \text { in unfumigated soil }}{k E C}$

Where $\mathrm{kEC}=0.38[26]$.

\section{Estimation of soil loss during incubation}

Soil losses were measured by a rainfall simulator following a modified procedure by Nciizah and Wakindiki [27]. Briefly, rainfall was applied either as $8 \mathrm{~min}$ Single Rainstorm (SR). Three runs of rainfall simulations were conducted per soil sample. Splash cups filled with soil were saturated with distilled water. The samples were put under the rainfall simulator at an intensity of $360 \mathrm{mmh}^{-1}\left(\approx 60 \mathrm{mmh}^{-1}\right.$ natural rainstorm with time specific energy of $\left.1440 \mathrm{~J} \cdot \mathrm{m}^{-2} \cdot \mathrm{h}^{-1}\right)$ [28]. The high intensity was to compensate for short falling distance of $0.4 \mathrm{~m}$ used when calibrating the rainfall simulator. After each rainstorm, the splashed sediments collected in the splash plate were washed into a jar, oven dried at $105^{\circ} \mathrm{C}$ for $24 \mathrm{~h}$ and weighed.

\section{Data Analysis}

Sampling was not destructive and thus the data was analysed using repeated measures Analysis of Variance (ANOVA) to compare treatment means. Where sphericity assumptions could not be met, the Greenhouse-Geisser correction of P was used. Pearson's test was used to determine whether significant correlations existed between soil organic carbon, soil loss and the observed selected soil properties were also done. All data were analysed using JMP version 11.0.0 statistical software [29].

\section{Results and Discussion}

The description of the areas of soil associations and analysed primary particle size distribution and soil organic carbon prior to the incubation is shown in Table 1 . The shallow soils had most primary mineral particles in the sand $(2-0.05 \mathrm{~mm} \varnothing)$ class and the melanic had most clay $(<0.002 \mathrm{~mm} \varnothing)$ content. The total soil organic carbon content of the soil associations ranged from 0.39 to $1.35 \%$ with the least $(0.39 \%)$ and highest (1.35\%) observed in the melanic and apedal respectively.

The $\mathrm{C} / \mathrm{N}$ ratio was used as an indicator for litter quality in this study. The V. karroo leaf had a lower (23.0) $\mathrm{C} / \mathrm{N}$ ratio than the $Z$. mays stover $(\mathrm{C} / \mathrm{N}=41.0)$. Besides the low $\mathrm{C} / \mathrm{N}$ ratio, the $V$. karroo leaf litter had more of ADF lignin $(\mathrm{L})$, Polyphenols $(\mathrm{P})$ and higher $(\mathrm{L}+\mathrm{P}) / \mathrm{N}$ ratio than the Z. mays stover (Table 2).

\begin{tabular}{|c|c|c|}
\hline Parameter & Vachellia karroo leaf & Zea mays stover \\
\hline Total C (\%) & $45.0 \pm 1.45$ & $49 \pm 0.25$ \\
\hline Total N (\%) & $2.0 \pm 0.09$ & $1.2 \pm 0.38$ \\
\hline C/N ratio & $23.0 \pm 1.78$ & $41.0 \pm 0.5$ \\
\hline ADF lignin (L) & $9.0 \pm 0.02$ & $3.0 \pm 0.10$ \\
\hline Polyphenols (P) & $1.6 \pm 0.01$ & $1.3 \pm 0.03$ \\
\hline (L+P)/N ratio & $5.3 \pm 0.37$ & $3.6 \pm 0.5$ \\
\hline
\end{tabular}

Table 2: Selected chemical characteristics of Vachellia karroo leaf and Zea mays litter used in the study.
The SOC content during the 34 weeks of incubation was significantly $(\mathrm{P}<0.05)$ influenced by the soil association $\times$ litter and soil moisture, time $\times$ soil association and the time $\times$ litter and soil moisture interactions. Estimated soil loss (SL) and the microbial biomass carbon $(\mathrm{MBC})$ were significantly $(\mathrm{P}<0.05)$ influenced by the time $\times$ soil type $\times$ litter and soil moisture interactions (Table 3 ).

The SOC was significantly $(\mathrm{P}<0.05)$ higher under the alternating wet-dry than in the continuously wet soil moisture conditions. The SOC content (\%) was highest in the melanic and lowest in the shallow, wet, apedal and duplex soil associations under the alternating wet-dry and continuously wet soil moisture conditions respectively (Table 4).

The results of previous studies showed that SOC content rapidly decrease when microbial biomass is high [30]. The soil moisture regimes affected organic carbon mineralization where the organic matter decomposed and mineralized more rapidly in continuously wet than under alternating wet-dry moisture conditions. As the soil moisture level was maintained at $80 \%$ field capacity, the SOC was quickly mineralized because of increased oxygen availability that promoted microbial respiration which decreased with time of incubation [31]. Although, it is observed that the organic matter quality influences the SOC and microbial biomass carbon [32], in this study the litter quality effects was the same in a soil association but varied across the soil associations. These results are not similar to observations by Potthast et al. [14] who observed that addition of higher quality substrate (lower $\mathrm{C} / \mathrm{N}$ ratio of $<24$ and lower lignin content) leads to a higher SOC mineralization than the lower quality $(\mathrm{C} / \mathrm{N}>24)$ organic matter. This could be due to low quality $V$. karroo leaf compared to $Z$. mays stover classified as intermediate quality (Table 2) and associated with just a balance of immobilization and mineralization. This may have been caused by the aging of the $V$. karroo leaves, which were harvested at the beginning of winter period (May). However, the results agreed with [13], who observed that $\mathrm{C} / \mathrm{N}$ ratio had no influence on different forest litter material and suggested other factors such as lignin/ $\mathrm{N}$ ratio or secondary metabolites like polyphenols to influence decomposability of litter.

Soil organic carbon content in the soil associations significantly $(\mathrm{P}<0.05)$ decreased with time and was lowest at week 34 in all soil associations. The SOC was significantly $(\mathrm{P}<0.05)$ higher $(1.56 \%)$ in the

\begin{tabular}{|c|c|c|c|c|}
\hline \multicolumn{5}{|c|}{ Source of variation } \\
\hline Between subjects & \multicolumn{2}{|c|}{ SOC } & SL & MBC \\
\hline \multirow{2}{*}{ Soil association (S) } & $\mathrm{F}_{4,62}$ & 14.41 & 558.4 & 112 \\
\hline & $\mathrm{P}$ & $<0.0001$ & $<0.0001$ & $<0.0001$ \\
\hline \multirow{2}{*}{ Litter (L) } & $\mathrm{F}_{3,62}$ & 168.76 & 650 & 8.9 \\
\hline & $\mathrm{P}$ & $<0.0001$ & $<0.0001$ & $<0.0001$ \\
\hline \multirow{2}{*}{$S \times L$} & $F_{11,62}$ & 2.2656 & 46.8 & 5.8 \\
\hline & $\mathrm{P}$ & 0.0253 & $<0.0001$ & 0.0146 \\
\hline Within subject & \multicolumn{2}{|c|}{ soc } & SL & MBC \\
\hline \multirow{2}{*}{ Time (T) } & $\mathrm{F}_{3,62}$ & 323.14 & 2360.6 & 240 \\
\hline & $\mathrm{P}$ & $<0.0001$ & $<0.0001$ & $<0.0001$ \\
\hline \multirow{2}{*}{$\mathrm{T} \times \mathrm{S}$} & $F_{12,62}$ & 4.385 & 166.4 & 9.4 \\
\hline & $\mathrm{P}$ & $<0.0001$ & $<0.0001$ & $<0.0001$ \\
\hline \multirow{2}{*}{$\mathrm{T} \times \mathrm{L}$} & $\mathrm{F}_{9,62}$ & 4.7657 & 192.7 & 12.3 \\
\hline & $\mathrm{P}$ & $<0.0001$ & $<0.0001$ & $<0.0001$ \\
\hline \multirow{2}{*}{$\mathrm{T} \times \mathrm{S} \times \mathrm{L}$} & $F_{36,62}$ & 1.5814 & 13.8 & 6.8 \\
\hline & $\mathrm{P}$ & $0.0606^{\mathrm{ns}}$ & $<0.0001$ & $<0.0001$ \\
\hline \multicolumn{5}{|c|}{ ns: Not Significant at $p=0.05$} \\
\hline
\end{tabular}

Table 3: Repeated measures of Analysis of Variance (ANOVA) for Soil Organic Carbon (SOC), Soil Loss (SL) and Microbial Biomass Carbon (MBC) during the 34 weeks of incubation. 
Citation: Parwada C, van Tol J (2017) Stability of Soil Organic Matter and Soil Loss Dynamics under Short-term Soil Moisture Change Regimes. Agrotechnology 6: 159. doi: 10.4172/2168-9881.1000159

Page 5 of 8

melanic at week 3 and lower $(<0.6 \%)$ in the shallow, wet, semi-duplex, apedal and duplex at week 34 of incubation. At weeks 3 and 14, the SOC was significantly $(\mathrm{P}<0.05)$ the same in the shallow, wet and duplex soil associations (Figure 2).

The SOC content depends on the balance between $\mathrm{C}$ input and decomposition rates [33]. The general decrease in SOC content with

\begin{tabular}{|c|c|c|c|}
\hline Soil association & Horizons & Litter $\times$ soil moisture & SOC (\%) \\
\hline \multirow{4}{*}{ Shallow } & \multirow{4}{*}{ Orthic A } & $W D \times Z$. mays & $1.06476^{b}$ \\
\hline & & $W D \times V$. karroo & $0.99302^{\mathrm{bc}}$ \\
\hline & & $W \times Z$. mays & $0.71802^{c}$ \\
\hline & & $W \times V$. karroo & $0.80671^{c}$ \\
\hline \multirow{4}{*}{ Wet } & \multirow{4}{*}{ G-horizon } & $W D \times Z$. mays & $1.03227^{b}$ \\
\hline & & $W D \times V$. karroo & $1.02148^{b}$ \\
\hline & & $W \times Z$. mays & $0.62905^{c}$ \\
\hline & & $W \times V$. karroo & $0.63105^{c}$ \\
\hline \multirow{4}{*}{ Melanic } & \multirow{4}{*}{ Melanic A } & $W D \times Z$. mays & $1.44851^{\mathrm{a}}$ \\
\hline & & $W D \times V$. karroo & $1.48198^{a}$ \\
\hline & & $W \times Z$. mays & $0.98719^{b c}$ \\
\hline & & $W \times V$. karroo & $0.99271^{\mathrm{bc}}$ \\
\hline \multirow{4}{*}{ Semi-duplex } & \multirow{4}{*}{ Pedocutanic B } & $W D \times Z$. mays & $1.30395^{\mathrm{ab}}$ \\
\hline & & $W D \times V$. karroo & $1.19019^{\mathrm{ab}}$ \\
\hline & & $W \times Z$. mays & $1.00040^{\mathrm{bc}}$ \\
\hline & & $W \times V$. karroo & $1.00490^{\mathrm{bc}}$ \\
\hline \multirow{4}{*}{ Apedal } & \multirow{4}{*}{ Red Apedal } & $W D \times Z$. mays & $1.22038^{\mathrm{ab}}$ \\
\hline & & $W D \times V$. karroo & $1.30448^{\mathrm{ab}}$ \\
\hline & & $W \times Z$. mays & $0.80026^{c}$ \\
\hline & & $W \times V$. karroo & $0.80036^{c}$ \\
\hline \multirow{4}{*}{ Duplex } & \multirow{4}{*}{ Prismacutanic B } & $W D \times Z$. mays & $1.01719^{b}$ \\
\hline & & $W D \times V$. karroo & $1.00197^{\mathrm{bc}}$ \\
\hline & & $W \times Z$. mays & $0.81432^{\mathrm{c}}$ \\
\hline & & $W \times V$. karroo & $0.83170^{c}$ \\
\hline
\end{tabular}

Table 4: Effects of litter source and soil moisture on the soil organic carbon content in the different areas of soil associations during the 34 week of incubation. time of incubation could be due to the diminishing of the substrate (organic matter) due to microbial decomposition as there was no replacement. The higher SOC observed in the melanic at week 3 than in the other soil associations could be due to the higher pore volume due to more clay particles in the soils. Physical occlusion of SOM during microaggregates formation has been observed as the most important processes by which the SOM can circumvent decomposition. The exclusion of microbes and enzymes from pores is the key protection mechanism for occluded SOM in microaggregates. The pore volume at $<0.1 \mu \mathrm{m} \varnothing$ is about $21 \%$ of pore volume present in microaggregates [34]. The accessibility of microbes to the occluded SOM is restricted due to the ratio between dimensions of the microhabitat and the size of the organism. However, it is observed that higher diversity of microbial respiration in silt and clay $(<0.002 \mathrm{~mm} \varnothing)$ fractions, which may be due to higher nutritional availability and exclusion from microbial decomposition [35].

The effect of litter source and soil moisture on the SOC content was significantly $(\mathrm{P}<0.05)$ the same at any incubation time. Same SOC content was observed under both continuously wet and alternating wet-dry soil moisture conditions at week 3 but the alternating wet-dry had more SOC content than continuously wet soil conditions in the subsequent weeks upto week 34 (Figure 3).

Estimated soil losses ( $\mathrm{t} / \mathrm{ha}$ ) increased with time of incubation under both the continuously wet and alternating wet-dry soil conditions and were lowest and highest at week 3 and 34 of incubation respectively in all the soil associations. The soil losses were generally higher in the continuously wet $(\mathrm{W} \times V$. karroo and $\mathrm{W} \times Z$. mays $)$ than in the alternating wet-dry $(\mathrm{WD} \times V$. karroo and $\mathrm{WD} \times Z$. mays $)$ conditions in all the soil associations. The duplex and apedal had significantly $(\mathrm{P}<0.05)$ the highest estimated soil losses under all litter source and soil moisture treatments. The melanic had significantly $(\mathrm{P}<0.05)$ the least estimated soil losses compared to the other soil associations (Figure 4).

Microbial biomass during the incubation was measured by Microbial Biomass Carbon (MBC) $(\mu \mathrm{g} / \mathrm{g})$, and all the litter source and

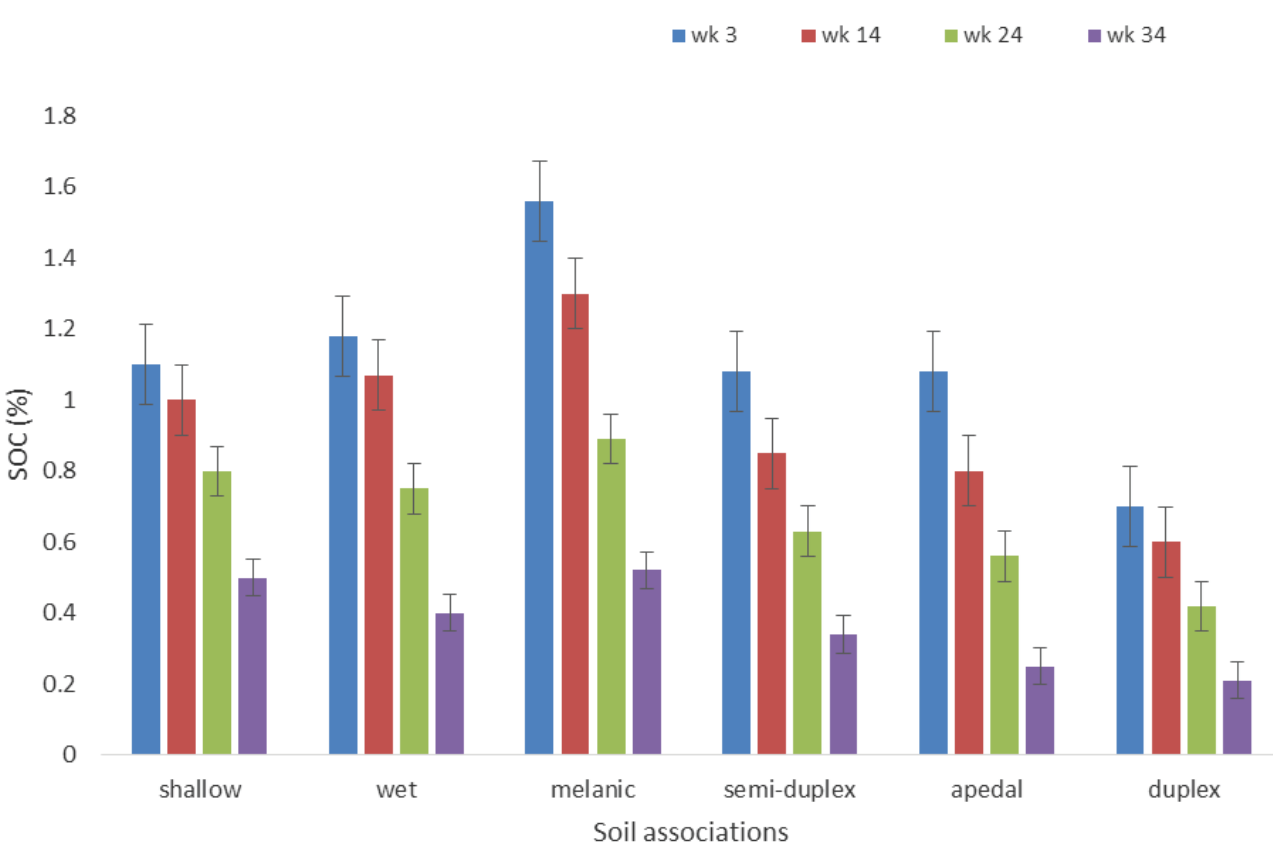

Figure 2: Trend of soil organic carbon content in the soil associations during the 34 weeks of incubation. 
Citation: Parwada C, van Tol J (2017) Stability of Soil Organic Matter and Soil Loss Dynamics under Short-term Soil Moisture Change Regimes. Agrotechnology 6: 159. doi: 10.4172/2168-9881.1000159

Page 6 of 8

soil moisture treatment combinations significantly influenced changes in microbial biomass $(\mathrm{P}<0.05)$. The $\mathrm{MBC}(\mu \mathrm{g} / \mathrm{g})$ varied according to the soil associations, decreased with time of incubation and ranged from highest at week 3 to lowest at week 34 of incubation in the shallow, wet and duplex, while was significantly $(\mathrm{P}<0.05)$ highest at week 24 and 34 in the melanic, semi-duplex and apedal soil associations. Same MBC was observed under both the continuously wet and alternating wet-dry soil moisture condition at weeks 3 and 14 but significantly $(\mathrm{P}<0.05)$ decreased under the continuously wet soils at weeks 24 and 34 of incubation in the shallow, wet and duplex (Figure 5).

The high contents of MBC generally indicate better soil quality. There is a general agreement that soil microbial activity has an optimal value when the soil is wet (but not saturated) and decreases at when the soil becomes dry. The reduction in microbial biomass carbon in alternating wet-dry soils observed as from week 24 of incubation could be mostly attributed to water and oxygen limitation of microbial activity: as matric suction increases soil water is held in pores inaccessible to microbes [36]. High microbial biomass carbon under the continuously wet soil moisture in the shallow, wet and duplex at week 3 and 14 may be ascribed to the presence of large soil pore spaces as the soil associations had higher sand content (Table 1) so the organic matter was readily available the soil microbes hence they proliferated. It is reported that $\mathrm{MBC}$ content has a positive relationship with soil moisture content [37]. The alternating wet-dry soil moisture could have resulted to reduction of the soil microbial action on the Organic Matter $(\mathrm{OM})$ due to moisture and oxygen limitation during the dry phases therefore prolonged the resident time of the OM in the soils. In this study, the MBC was observed to be highly controlled by the availability of OM in the soil (Figure 5). In some studies dry soils generally has low SOC and that carbon mineralization is faster than accumulation in this case, indicating that soil moisture significantly influences SOC content and MBC (reference). This does agree to the findings in this study, as the wet-dry soil moisture did preserve the soil organic matter.
Estimated soil loss was significantly $(\mathrm{P}<0.05)$ inversely proportional to the SOC content, soil clay content and time of incubation in the soil associations. The estimated soil losses were positively correlated with the MBC $(\mu \mathrm{g} / \mathrm{g})$ however the MBC was significantly negatively correlated $(\mathrm{P}<0.05)$ with the SOC content and time of incubation and positively correlated with the quantities of clay particle in soil associations (Table 5).

The results of many studies showed a close correlation between $\mathrm{MBC}$ and SOC because most microorganisms are heterotrophic and their distribution and biological activity often depend on organic matter [30]. It is found that litter sources that easily decomposes could make the soil microbes to multiply rapidly and increase their activities, suggesting that the MBC content is effectively limited SOC [38]. These results agrees to a study by Wardle when he found that MBC was significantly positively correlated with SOC. Soil texture is an important soil physical parameter of soil structure, with higher clay particle content indicating well structured, resulting in more pore spaces and high porosity, which are related to increased soil moisture and MBC [39-41]. Increase clay content may indicate that SOM is more protected against soil microbial decomposition and this could explain the higher SOC content and MBC in the melanic, semi-duplex and apedal soil associations (Figures 2, 4 and 5).

\begin{tabular}{|c|c|c|c|c|c|c|}
\hline & SL & SOC & MBC & Sand & Clay & Silt \\
\hline SOC & $-0.818^{* * *}$ & - & - & - & - & - \\
\hline MBC & $0.673^{\star *}$ & $-0.738^{\star * *}$ & - & - & - & - \\
\hline Sand & -0.31 & -0.415 & -0.302 & - & - & - \\
\hline Clay & $-0.715^{\star * *}$ & $0.623^{\star *}$ & $0.563^{\star *}$ & 0.008 & - & - \\
\hline Silt & 0.421 & 0.392 & 0.043 & 0.21 & -0.043 & - \\
\hline Time & $-0.846^{* * *}$ & $-0.918^{\star * *}$ & $-0.824^{* * *}$ & 0.031 & $-0.615^{\star *}$ & 0.31 \\
\hline
\end{tabular}

SL: Stimated Soil Loss (t/ha): SOC: Soil Organic Carbon; MBC: Microbial Biomass Carbon; **Significant at $\mathrm{P}<0.05$; ${ }^{* * *}$ Significant at $\mathrm{P}<0.001$

Table 5: Pearson correlation matrix between soil loss ( $\mathrm{t} / \mathrm{ha}$ ) and selected observed soil properties during the 34 weeks (time) of incubation.

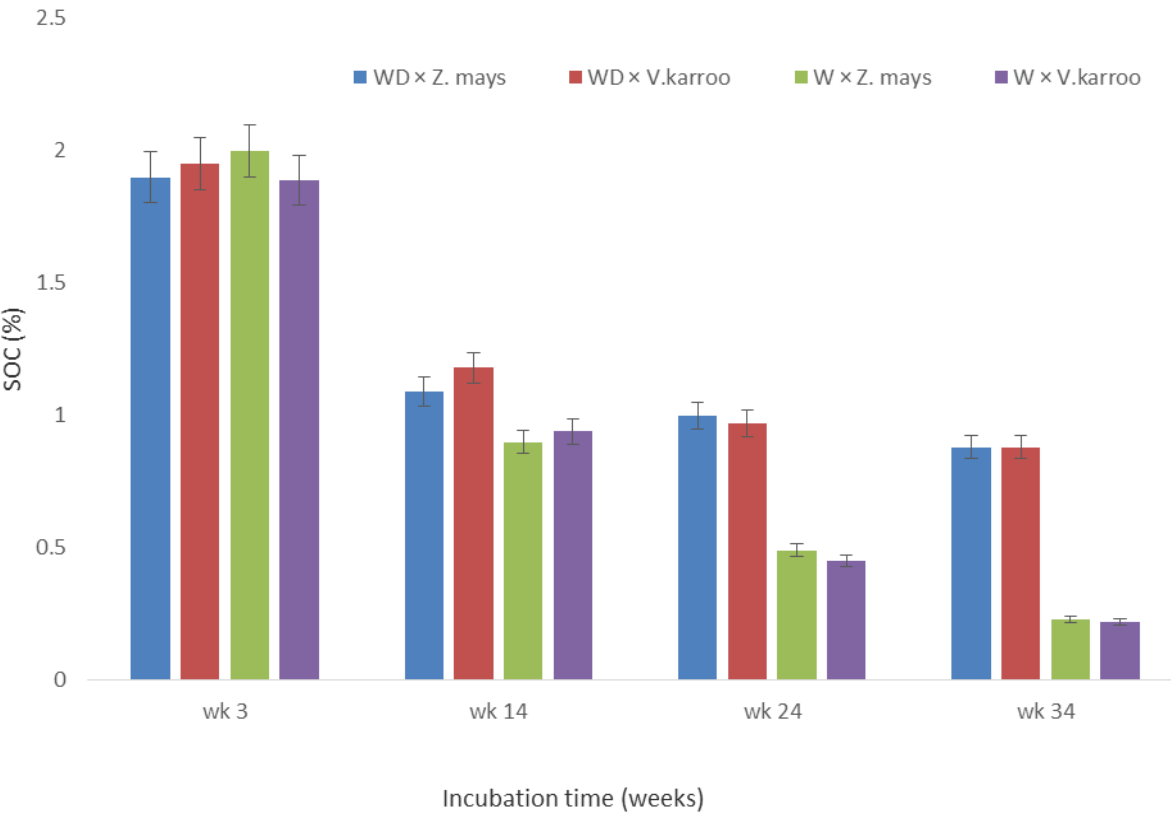

Figure 3: Effects of litter source and soil moisture on the soil organic carbon content as influenced by the time of incubation. 
Citation: Parwada C, van Tol J (2017) Stability of Soil Organic Matter and Soil Loss Dynamics under Short-term Soil Moisture Change Regimes. Agrotechnology 6: 159. doi: 10.4172/2168-9881.1000159

Page 7 of 8

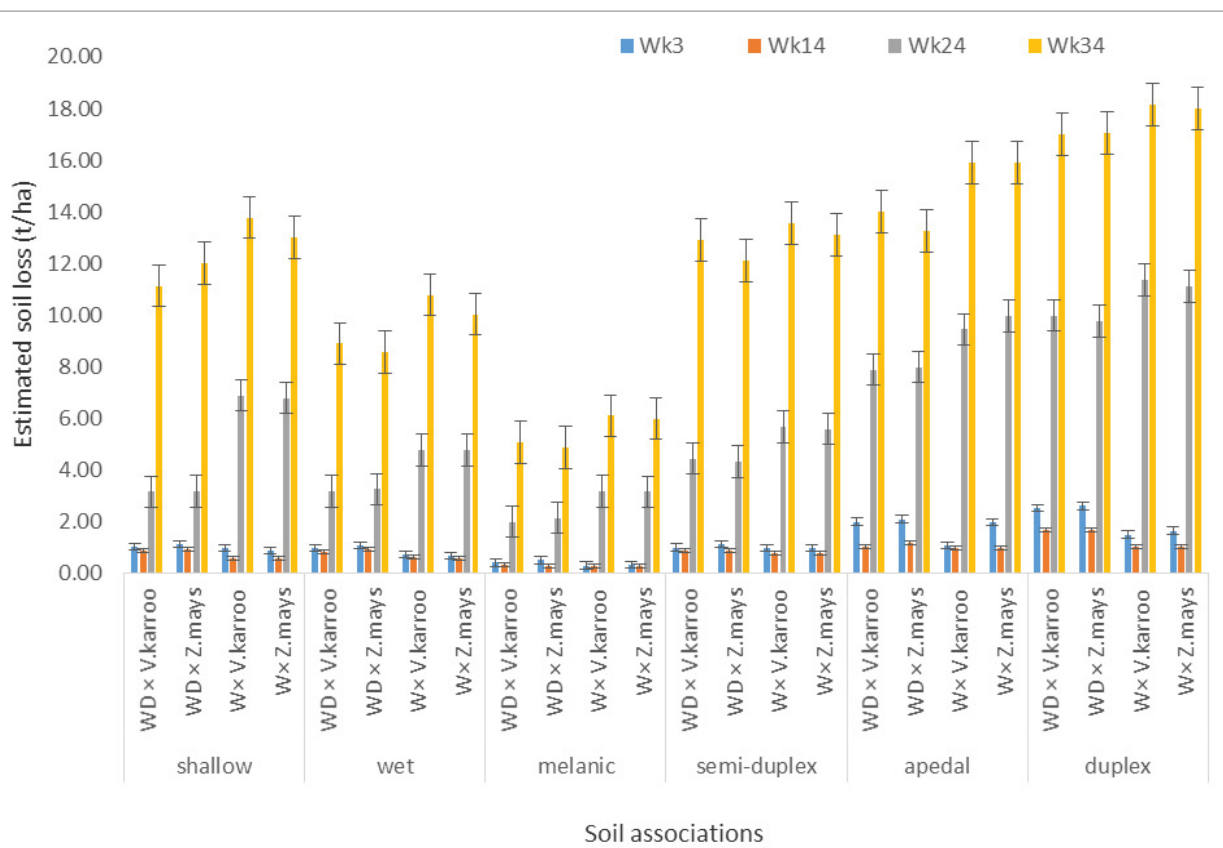

Figure 4: Estimated soil loss (t/ha) among the soil associations under different litter sources and soil moisture during the 34 weeks of incubation.

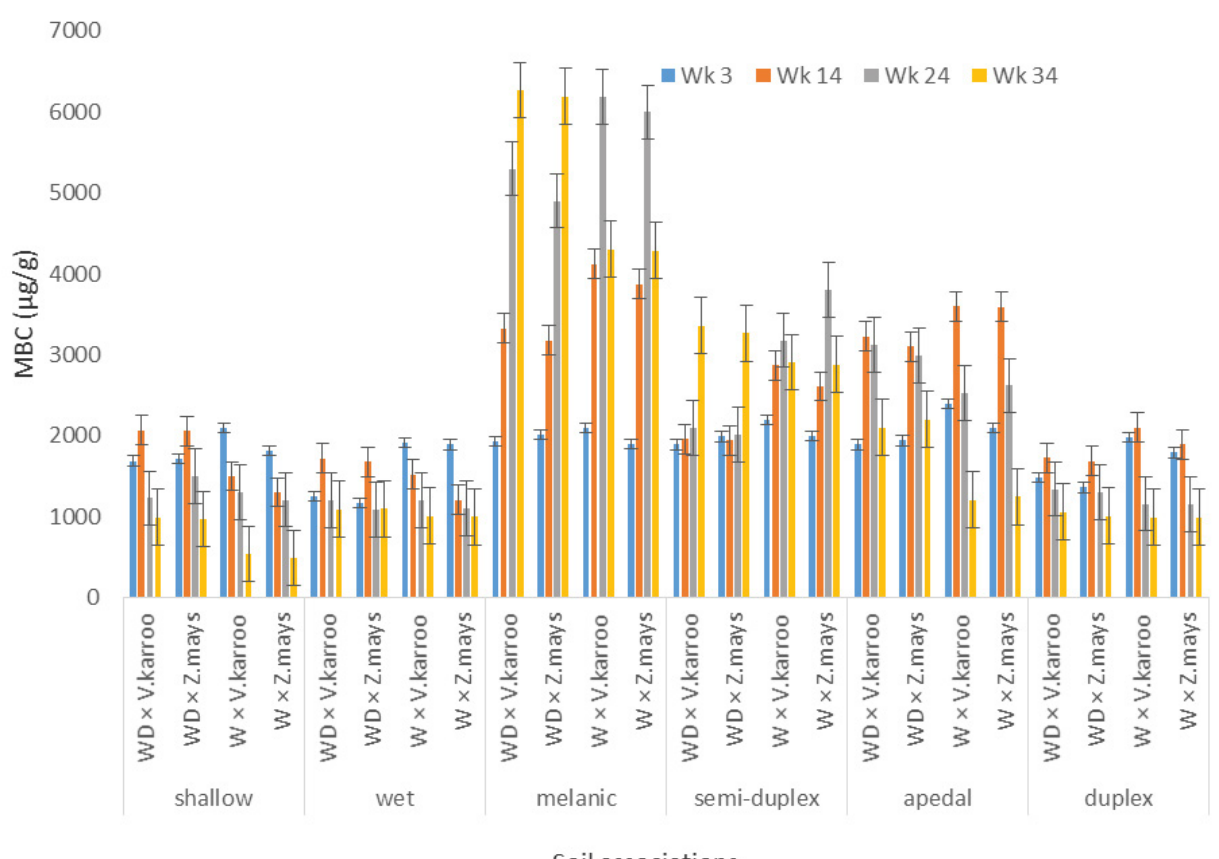

Figure 5: The microbial biomass carbon $(\mu \mathrm{g} / \mathrm{g})$ means during the 34 weeks of incubation.

\section{Conclusion and Recommendations}

The SOC content, MBC and soil loss in the soil associations were controlled by the soil texture and moisture content. Continuously wet sandy soils influenced more SOC loss, lower MBC and higher soil loss than soils higher in clay particles. The soil loss was proportional to the SOC and MBC at any time of incubation. Availability of OM under continuously wet sandy soil promoted rapid loss of SOC and soil from the soil associations. The alternating wet-dry moisture conditions showed to prolong the SOM resident time in all the soil associations though most SOM was conserved soils high in clay particles. Litter quality and soil moisture did not affect the SOC, MBC and soil loss within but affected across soil associations. Therefore addition of fast decomposing organic matter to the continuously wet sandy soils is likely to increase the climatic warming so has to be regulated. In conserving the soil from erosion, re-application of fresh organic matter has to be done after shorter times in the continuously wet sandy than under alternating wet-dry clay soil moisture regimes. 
Citation: Parwada C, van Tol J (2017) Stability of Soil Organic Matter and Soil Loss Dynamics under Short-term Soil Moisture Change Regimes. Agrotechnology 6: 159. doi: 10.4172/2168-9881.1000159

Page 8 of 8

\section{Acknowledgements}

The authors gratefully acknowledge the Agricultural Research Council for funding received for the study as well as the Water Research Commission for financial support to the first author.

\section{References}

1. IPCC (2007) Climate change 2007. The physical science basis, coupling between changes in the climate systems and biogeochemistry. Contribution of working group 1 to the fourth assessment report of the intergovernmental panel on climate change. Cambridge university press: Cambridge, UK and NY, USA.

2. Jobbagy EG, Jackson RB (2000) The vertical distribution of soil organic carbon and its relation to climate and vegetation. Ecol Applications 10: 423-436.

3. Davidson EA, Janssens IA (2006) Temperature sensitivity of soil carbon decomposition and feedbacks to climate change. Nature 440: 165-173.

4. Smith P, Fang C, Dawson JJC, Moncrieff JB (2008) Impact of global warming on soil organic carbon. Adv Agron 97: 1-43.

5. Cox PM, Betts RA, Jones CD, Spall SA, Totterdell IJ (2000) Acceleration of global warming due to carbon-cycle feedbacks in a coupled climate model. Nature 408: 184-187

6. Davidson EA, Janssens IA, Luo Y (2006) On the variability of respiration in terrestrial ecosystems: moving beyond $Q_{10}$. Global Change Biol 12: 154-164.

7. Curiel Yuste J, Baldocchi DD, Gershenson A, Goldstein A, Misson L, et al (2007) Microbial soil respiration and its dependency on carbon inputs, soil temperature and moisture. Global Change Biol 13: 2018-2035.

8. Liu W, Zhang Z, Wan S (2009) Predominant role of water in regulating soil and microbial respiration and their responses to climate change in semiarid grassland. Global Change Biol 15: 184-195.

9. Guntinas ME, Gil-Sotres F, Leiros MC, Trasar-Cepeda C (2013) Sensitivity of soil respiration to moisture and temperature. J Soil Sci Plant Nutr 13: 445-461.

10. Chivenge P, Vanlauwe B, Gentile R, Six J (2011) Comparison of organic versus mineral resource effects on short-term aggregate carbon and nitrogen dynamics in a sandy soil versus a fine textured soil. Agric Ecosy Environ 140: 361-371.

11. Puttaso A, Vityakon P, Rasche F, Saenjan P, Trelo-ges V, et al. (2013) Does organic residue quality influence carbon stabilization in tropical sandy soil? Soil Sci Soc Am J 77: 1001-1011.

12. Fierer N, Jackson RB (2006) The diversity and biogeography of soil bacterial communities. Proc Natl Acad Sci USA 103: 626-631.

13. Jacobs A, Helfrich M, Hanisch S, Quendt U, Rauber R, et al. (2010) Effect of conventional and minimum tillage on physical and biochemical stabilization of soil organic matter. Bio Fert Soils 46: 671-680.

14. Potthast K, Hamer U, Makeschin F (2010) Impact of litter quality on mineralization processes in managed and abandoned pasture soils in Southern Ecuador. Soil Biol Biochem 42: 56-64

15. Dick WA, Gregorich EG (2004) Developing and maintaining soil organic matter levels. In: Managing Soil Quality Challenges in Modern Agriculture. CAB Publishing, Wallingford

16. Bhogal A, Nicholson FA, Chambers BJ (2009) Organic carbon additions: effects on soil bio-physical and physico-chemical properties. Eur J Soil Sci 60: 276-286.

17. Gentile R, Vanlauwe B, Six J (2011) Litter quality impacts short- but not long-term carbon dynamics in soil aggregate fractions. Ecol Applications 21: 695-703.

18. Cerda A (2000) Aggregate stability against water forces under different climates on agriculture land and scrubland in southern Bolivia. Soil Till Res 57: 159-166.

19. Van Tol JJ, Akpan W, Lange D, Bokuva C, Kanuka G, et al. (2014) Conceptualising long term monitoring to capture environmental, agricultural and socio-economic impacts of the Mzimvubu Water Project in the Tsitsa River. WRC project No: KV 328/14. Water Research Commission.

20. Van Tol JJ, Akpan W, Kanuka G, Ngesi S, Lange D (2014) Soil erosion and dam dividends: Science facts and rural 'fiction' around the Ntabelanga dam, Eastern Cape, South Africa. SA Geo J 98: 169-181.

21. Anderson JM, Ingram JJ (1993) Tropical soil biology and fertility (TSBF): A handbook of methods. Wallingford, UK, CAB International.
22. Hagerman AE (1988) Extraction of tannin from fresh and preserved leaves. Chem Ecol 14: 453-461.

23. Okalebo JB, Gathua KW, Woomer PL (2000) Laboratory methods of soil and plant analysis: A Working Manual. TSBF-KARI-UNESCO, Nairobi, Kenya.

24. Chan KY, Bowman A, Oates A (2001) Oxidizible organic carbon fractions and soil quality changes in an oxic paleustalf under different pasture leys. Soil Sci 166: 61-67.

25. Joergensen RG, Emmerling C (2006) Methods for evaluating human impact on soil microorganisms based on their activity, biomass, and diversity in agricultural soils. J Plant Nutr Soil Sci 169: 295-309.

26. Vance ED, Brookes PC, Jenkinson DS (1987) An extraction method for measuring soil microbial biomass-C. Soil Biol Biochem 19: 703-707.

27. Nciizah AD, Wakindiki IIC (2014) Rainfall intensity effects on crusting and mode of seedling emergency in some quartz-dominated South African Soils. Water SA $40: 4$.

28. Martin C, Pohl M, Alewell C, Korner C, Rixen C (2010) Interrill erosion at disturbed alpine sites: Effects of plant functional diversity and vegetation cover Basic Appl Ecol 11: 619-626.

29. SAS Institute Inc (2010) SAS campus drive. Cary, North Carolina, USA

30. Yang Y, Guo J, Chen G (2009) Effects of forest conversion on soil labile organic carbon fractions and aggregate stability in subtropical China. Plant Soil 323 153-162.

31. Mission L, Tang J, Xu M, McKay M, Goldstein A (2005) Influences of recovery from clear-cut, climate variability, and thinning on the carbon balance of a young ponderosa pine plantation. Agric Forest Met 130: 207-222.

32. Wang YF, Fu BJ, Lv YH, Song CJ, Luan Y (2010) Local-scale spatial variability of soil organic carbon and its stock in the hilly area of the Loess Plateau. China Quat Res 73: 70-76.

33. Huang J, Song C (2010) Effects of land use on soil water soluble organic C and microbial biomass $C$ concentrations in the Sanjiang plain in Northeast China. Acta Agric Scand, Section B-Plant Soil Sci 60: 182-188.

34. McCarthy JF, llavsky J, Jastrow JD, Mayer LM, Perfect E, et al. (2008) Protection of organic carbon in soil microaggregates occur via restructuring of aggregate porosity and filling pores with accumulating organic matter. Geochi. Cosmoch. Acta 72: 4725-4744.

35. Sessitch A, Weilharter A, Gerzabek MH, Kirchmann H, Kandele E (2001) Microbial population structures in soil particle size fractions of a long-term fertilizer field experiment. App Environ Microbiol 67: 4215-4224.

36. Falloon P, Jones CD, Ades M, Paul K (2011) Direct soil moisture controls of future global soil carbon changes: An important source of uncertainty. Glob Biogeochem Cycles 25.

37. Devi NB, Yadava PS (2006) Seasonal dynamics in soil microbial biomass C, N and $P$ in a mixed-oak forest ecosystem of Manipur, North-east India. Appl Soil Ecol 31: 220-227.

38. Landgraf D, Klose $\mathrm{J}$ (2002) Mobile and readily available $\mathrm{C}$ and $\mathrm{N}$ fractions and their relationship to microbial biomass and selected enzyme activities in a sandy soil under different management systems. J Plant Nutr Soil Sci 165: 9-16.

39. IUSS Working Group WRB (2015) World Reference Base for Soil Resources 2014, update 2015, International soil classification system for naming soils and creating legends for soil maps. World Soil Resources Reports No. 106. FAO, Rome.

40. Parwada C, Van Tol JJ (2016) Soil properties influencing erodibility of soils in the Ntabelanga area, Eastern Cape Province, South Africa. Acta Agr Scan Section B-Soil Plant Sci 67: 67-76.

41. Soil Classification Working Group (1991) Soil classification a taxonomic system for South Africa. Memoirs on the Agricultural Natural Resources of South Africa No. 15. Department of Agricultural Development, Pretoria. 